\title{
TEORÍAS Y POLÉMICAS SOBRE LA RIMA EN EL RENACIMIENTO INGLÉS
}

\author{
JUAN FRAU
}

\begin{abstract}
Resumen: El propósito de este artículo es examinar las teorías del Renacimiento inglés sobre la rima y la polémica acerca de su conveniencia para la versificación inglesa. Los críticos y poetas isabelinos estaban divididos en dos facciones opuestas: una que defiende los modelos clásicos y trata de rescatar el verso cuantitativo, y por lo tanto rechaza la rima, y otra que acepta la rima como una característica esencial del verso de la época. Samuel Daniel, Thomas Campion, Philip Sidney y Edmund Spenser, entre otros, toman parte en este debate.
\end{abstract}

Palabras clave: Renacimiento, rima, versificación, Samuel Daniel, Thomas Campion, Philip Sidney, Edmund Spenser.

\begin{abstract}
The objective of this paper is to examine English Renaissance theories of rhyme and the polemic on its convenience to the English versification. Elizabethan critics and poets were divided into two opposite factions: one that defends the classical models and attempts to rescue the quantitative verse, and thereby rejects rhyme, and another that accepts rhyme as an essential characteristic of the verse of the period. Samuel Daniel, Thomas Campion, Philip Sidney and Edmund Spenser, among others, take part in this debate.
\end{abstract}

Key words: Renaissance, rhyme, versification, Samuel Daniel, Thomas Campion, Philip Sidney, Edmund Spenser. 

$\mathrm{E}$

L Renacimiento inglés resultó ser una época muy fértil en consideraciones teóricas sobre la poesía, en la que, en el corto espacio de apenas dos décadas, vieron la luz distintas obras de notable envergadura, difusión e influencia, tales como la Defensa de la poesía, de Philip Sidney, o The Art of English Poesy, de George Puttenham, junto a otras obras menores por su extensión pero que contribuyeron a enriquecer en un alto grado el panorama crítico. Se trata de escritos de muy diversa índole, por su intención y su estructura, tratados y ensayos que usan tanto el verso como la prosa o que, en alguna ocasión, se presentan bajo la forma clásica del diálogo. El espacio que en ellos se dedica a la reflexión sobre la rima es desigual, y el tratamiento no siempre adopta el aire polémico que le dan Thomas Campion, Samuel Daniel o Roger Ascham, pero se trata, en todo caso, de un tema que merece la atención y el interés de la mayoría de los críticos de aquel tiempo. Incluso un poeta como Ben Jonson participa en la discusión con un poema burlesco titulado "A fit of rhyme against rhyme", en el que parece reírse por igual de las posturas de Campion y Daniel.

Hay que tener presente la ambigüedad del término rhymel rime (con las vacilaciones gráficas del momento: rhime, ryme), que, tanto en la tradición inglesa como en distintas tradiciones románicas -ya lo observa Dante-, puede designar tanto el fenómeno eufónico basado en la repetición de sonidos como la propia composición poética en su conjunto. Esta polisemia puede observarse incluso en los títulos de las obras de la época; así, cuando Daniel publica $A$ Defence of Rhyme se refiere a la rima en sentido estricto, pero George Gascoine publica en 1575 Certayne Notes of Instruction Concerning the Making of Verse or 
Ryme in English, haciendo explícita la sinonimia entre rima y versificación mediante la construcción disyuntiva. En el contexto en el que nos hemos situado, sin embargo, la rima puede adoptar a veces un tercer referente, situado entre los otros dos, y aludir específicamente al verso silábico y rimado, frente a aquel otro que trata de seguir los modelos grecolatinos. En realidad, este último sentido no es del todo ajeno a Daniel, y más adelante será obligado tratar esta diferencia con algo más de detenimiento.

Prueba de la polisemia del término es el uso que llegan a hacer Sidney y Campion de la expresión "to rhyme a man to death", que podría traducirse como rimar hasta la muerte o, más exactamente, matar a un hombre a rimas. La palabra rimas, en este contexto, equivale a composiciones rimadas, pero se refiere específicamente a maldiciones o encantamientos malignos que los bardos -Sidney se refiere a los irlandeses en concreto- podían lanzar sobre sus enemigos para causarles algún tipo de perjuicio, incluso la muerte (SIDNEY, 2004: 54; CAMPION, 2004: 282).

De entre los tratados principales de este periodo, seguramente el de composición más antigua -también el más célebre- es el de Sidney, terminado según todos los indicios entre 1581 y 1583, aunque durante bastantes años circuló manuscrito entre un círculo reducido de intelectuales y poetas y no se publicó hasta 1595. Como es bien sabido, se trata de un ensayo que expone una serie de consideraciones generales y teóricas sobre la poesía, con el propósito fundamental de contrarrestar la visión platónica sobre su inutilidad y sus posibles efectos perniciosos. Guiado por esa prioridad, Sidney, a diferencia de Puttenham o Daniel, no profundiza demasiado en los aspectos técnicos, como los atingentes a la versificación, fundamentalmente porque considera que "one may be a poet without versing, and a versifier without poetry" (2004: 32). Dentro de la polémica que ya previamente habían sostenido los tratadistas italianos, donde autores como Robortello, Escalígero o Minturno ${ }^{1}$ defienden que no

\footnotetext{
${ }^{1}$ Aceptamos la interpretación de Weinberg, quien señala que Minturno sigue a Aristóteles cuando afirma que el verso no es esencial en la poesía, sino la imitación, pero "en todos los demás pasajes el verso es parte integrante de su concepción de la poesía”. (2003: 154).
} 
hay poesía si no hay verso, Sidney opta por considerar que lo que verdaderamente define y distingue los textos literarios es su carácter ficcional, en tanto que el verso es un asunto meramente formal que no cambia la esencia de la obra, pues "no son la rima y el verso los que hacen a la poesía" (2003: 157). Por ello, las reflexiones sobre el verso aparecen sólo una vez que Sidney ha utilizado los argumentos que entiende más valiosos en su apología de la creación, como su carácter ejemplar y lo ventajoso de poder dibujar una perfección que es imposible encontrar en la realidad. Sólo entonces se permite añadir el siguiente razonamiento (2003: 157):

"No puede quedar sin elogio aquello que mejor da lustre a esa bendición que es el lenguaje, que considera cada palabra no sólo según el acento, como alguno dirá, sino según la cantidad; y ambos, acento y cantidad, llevan incluso en sí mismos una armonía."

Sidney reconoce, pues, que, aunque no sea lo esencial del texto literario, las cualidades rítmicas del verso aportan valores dignos de reconocimiento que lo elevan aún más sobre el uso ordinario del lenguaje. Sin embargo, poco seguro de que la excelencia formal pueda convencer a los detractores de la poesía, pasa de inmediato a centrarse en aspectos prácticos de la versificación y de la rima. En este sentido, la razón de más peso en su favor es "el hecho de que el verso supere con mucho a la prosa en la fijación de la memoria", debido a que las palabras "se disponen de tal forma que una no puede perderse sin que la obra entera falle; cuando se acusa esto, se despierta la memoria y así la consolida con más firmeza" (2003: 157).

Sidney se refiere aquí al conjunto de las cualidades estructurales del verso, que provocan que nada pueda alterarse sin echar a perder el conjunto, lo que obliga a conservar la obra tal cual es y a recordar, por lo tanto, cada palabra y en su orden -en esto, en cierto modo, Sidney se encuentra a medio camino entre la idea de la retórica clásica de la dispositio, que consiste en situar cada elemento allí donde es más efectivo, y la defensa que se hará en el siglo XX de la literalidad del texto poético-. Sorprende 
a su vez, por esa misma especie de anticipación, la idea que desarrolla acto seguido, cuando sostiene que, en el verso, una palabra "engendra la otra de tal suerte que, ya sea verso rimado o métrico, por la que precede se tendrá una conjetura aproximada de la que sigue", formulación que se asemeja, de modo parcial y con las debidas matizaciones, a algunas de las consideraciones hechas más de tres siglos después por los formalistas respecto al carácter apriorístico del ritmo del verso, o a los conceptos que propone Oldrich Belic de "expectativa" o de "impulso rítmico" (2000: 44-5), que emplea para explicar precisamente la constante y renovada previsión que, en el plano rítmico, va haciendo el receptor durante la lectura. En todo caso, y en lo que atañe a la rima, conviene subrayar que Sidney, a diferencia de otros de sus contemporáneos, no destaca su potencial como recurso mnemotécnico; para él, cualquier tipo de verso ayuda a la memoria, y cuando dice "as be it in rime or measured verse" está equiparando en ese aspecto los dos modelos que coexistían -y contendían- en la época: el verso métrico que sigue los modelos grecolatinos y el verso rítmico, rimado. En la misma línea, Sir John Harington afirma que el verso tiene múltiples buenos usos, como el servir de ayuda a la memoria mejor que la prosa (1815: 128-9), "puesto que las palabras están dispuestas juntas en el debido orden, medida y número" (1815: 131)², pero tampoco menciona específicamente la rima.

Aunque Sidney o Harington no lo hagan, sí suelen destacar este valor de la rima otros tratadistas. Lo hace, por ejemplo, George Puttenham, que según parece comenzó a componer su obra antes que Sidney la suya -la concluyó, no obstante, cuando éste ya había muerto-, y que, al igual que Sidney, afirma que el metro es más fácil de retener en la memoria, aunque el motivo que contribuye a ello en mayor medida, según él, es su brevedad, que contrasta con los largos períodos de la prosa (2004: 62). Más adelante subraya que el verso también es más eficaz e impresiona más el oído por la sonoridad que le confieren "so

\footnotetext{
${ }^{2}$ La traducción de todas las citas de Webbe, Puttenham, Wilson, Harington, Gascoigne, Ascham, Harvey, Spenser, Daniel y Campion se ha hecho para la presente ocasión, de manera que la página a la que remitimos es la del correspondiente texto original.
} 
gallant and harmonical accents", con lo que todavía no se refiere de forma clara y directa a la rima, aunque sin duda la tenga presente. Finalmente, en un capítulo posterior, sí hace explícita esa relación entre la rima y la memoria, cuando explica que, durante el período medieval, todo estudioso y clérigo que escribía sobre cualquier materia de interés usaba la rima, "lo que lo hacía más grato al lector y fácil de recordar" (2004: 67), algo que hace extensible a los proverbios y dichos populares.

Seguramente sea Daniel, en su Defensa de la rima, quien más insiste en este aspecto. Recoge en parte la idea que antes hemos visto expresada por Sidney cuando afirma que "todo verso no es sino una estructura de palabras confinadas dentro de una cierta medida, que difiere del discurso ordinario y que se introduce de la mejor forma para expresar los conceptos de los hombres, a la vez para el deleite y la memoria" (DANIEL, 2004: 210). Poco después insiste en el valor específico que para ello tiene la rima, que define y explica como "consistente en un sonido concordante en las últimas sílabas de varios versos, ofreciendo al oído el eco de una deleitosa correspondencia y a la memoria una impresión más profunda de lo que allí se transmite" (2004: 211). Y más tarde vuelve sobre la misma idea, refiriéndose a aquellas obras que conservan y difunden el saber y que, sin ser poéticas, utilizan el verso rimado: "Y eso en tan pocas palabras, tanto para el deleite del oído como para el apoyo de la memoria, que han de ser aceptadas por todos los lectores modestos que estudian para saber y no para difamar" (2004: 212).

Incluso William Webbe, pese a su rechazo general de la rima -bastante mesurado, en todo caso-, reconoce este valor y dice que no puede "sino rendirle (como la costumbre demanda) las merecidas alabanzas, especialmente donde está dispuesta con buen juicio" (1870: 64). Añade que la técnica de formular cualquier cosa en verso es un buen ejercicio de la memoria, y dice estar de acuerdo con Gascoigne cuando éste recomienda utilizar la versificación rimada para la enseñanza.

Hay que destacar que el argumento del valor de la rima como auxiliar de la memoria, pese a tratarse de una consideración cercana al tópico y la obviedad, tiene, sin embargo, una gran importancia en un contexto social, político y religioso en el que 
abundaban las críticas virulentas contra la supuesta inutilidad de la poesía. No conviene olvidar, por ejemplo, que como resultado de tales controversias, alimentadas sobre todo por el puritanismo, llegará a producirse la prohibición de las representaciones teatrales durante casi veinte años. La utilidad práctica del texto literario, por lo tanto, se convierte en un argumento esencial en el debate, y la rima puede llegar a justificarse más por tales motivos que por consideraciones sobre su eufonía o su papel en la estructura del poema.

En su Art of Rhetoric, publicada en los inicios de la era isabelina, Thomas Wilson trata el asunto de la rima desde el punto de vista de la retórica clásica, sin detenerse apenas en consideraciones métricas, y subraya también su utilidad, aunque en otro sentido. Defiende su eficacia como instrumento para la oratoria, pues deleita y capta la atención del público, siempre que se use con mesura. Expone que "algunos terminan sus sentencias de forma en todo semejante, haciendo que su locución antes parezca metro rimado que discurso llano, lo cual tanto deleita si se usa con mesura cuanto ofende cuando no se observa moderación" (1909: 168). Antes de aludir al ilustre precedente de San Agustín, lo ejemplifica con el caso concreto de un predicador que "solía con frecuencia terminar sus sentencias con palabras similares a las que venían antes, que a mi juicio no llegaban a la docena, pero que terminaban con rima en su mayor parte". El problema, dice Wilson con algo de sorna, es que el público menos dispuesto "desearía que el predicador hubiera tenido un laúd", que añadido al rimed sermon podría dar una placentera melodía al son de la que pudieran bailar. Y es que, concluye Wilson, "hay ciertamente una medida moderada, y no hay razón para usar ninguna cosa todo el tiempo, viendo que nada deleita (nunca sería tan bueno) si se usa siempre" (1909: 168).

El libro tercero de esta obra se dedica a la elocución, y en él se dedica un pequeño apartado a las figuras que Wilson denomina like ending and like falling, traducción del latín similiter desinens y similiter cadens. En ese apartado, ambas figuras - bien definidas pero que en medio de la profusión de ejemplos aparecen mezcladas con otras como el calambur, el retruécano o la paronomasiase ponen en relación con la rima. Además de insistir en que estas 
repeticiones son deleitosas siempre que se usen con moderación, y atractivas hasta el punto de que el público acostumbrado a las frases y los himnos con rima deja de soportar los sermones que no la usan, Wilson introduce una consideración interesante sobre el tipo de placer que produce la iteración fónica. Sostiene que el deleite de este tipo de ornamentación es mayor porque "cosas contrarias se unen en la repetición" y porque "aquello que se dijo antes se usa una vez más" (1909: 202). Aunque aquí están expuestos de una manera sucinta y embrionaria, son argumentos que llegarán a tener una importancia capital en la teoría literaria del siglo XX; recordemos cómo, según Jakobson, "en poesía, cualquier similitud sobresaliente en el sonido es evaluada respecto a una disimilitud en el contenido" y cómo, además, la rima provoca, entre otras cosas, que el lector vuelva a lo ya percibido (JAKOBSON, 1974: 156-163). Repetición y diferencia combinadas es, asimismo, lo que Wilson destaca, aunque no llega a desarrollar la idea.

En cuanto a la posible confusión de la rima con la similicadencia, Thomas Campion, cuatro décadas después, partirá de planteamientos semejantes a la hora de esgrimir uno de sus varios argumentos contra la rima. Afirma lo siguiente (2004: 283):

"Pero permitidme ahora examinar la naturaleza de aquello que llamamos rima. Por rima se entiende aquello que termina con sonido semejante, de modo que los versos compuestos en tal manera no producen sino una repetición continua de esa figura retórica que designamos similiter desinentia, y, no siendo ella sino figura verbi, debería (como Cicerón y todos los demás retóricos han observado juiciosamente) ser utilizada en poca cantidad, no sea que ofenda al oído con tediosa afectación”.

En este respecto, Campion está adaptando la doctrina a su conveniencia, pues, de una manera más objetiva y desapasionada, Puttenham había señalado unos años antes la diferencia entre ambos conceptos: afirmaba Puttenham que "ya los griegos y latinos usaban una forma de discurso basada en cláusulas de terminación semejante, que ellos llamaban homoioteleuton, y fue lo más cerca que ellos se aproximaron a nuestra rima, pero no es, propiamente, nuestra concordia" (2004: 121). 
Volviendo al libro de Wilson, el apartado dedicado a las repeticiones de sonidos finales concluye con una última defensa de la mesura en su uso, y, pese a señalar que son recursos placenteros y valiosos, el autor advierte -mezclando burlas y veras- del peligro que suponen para los ignorantes, que cuando escuchan los himnos religiosos rimados, dada la confluencia del canto, la música de los órganos, el tañido de las campanas y el rimado de las frases, "podrían pensar que la armonía es celestial, y creer que los ángeles de Dios no crearían un mejor sonido en el cielo" (1909: 203). Lo que hay que leer entre líneas en esta crítica, obviamente, es que Wilson entiende que la rima puede servir para atraer la atención del público sobre el texto, lo cual es una virtud notable, pero esa atracción puede convertirse en distracción si la musicalidad y los efectos sonoros terminan por imponerse y acaparar todo el protagonismo en detrimento del contenido. A fin de cuentas, se trata de un tratado de retórica, arte para el que lo fundamental es que el texto se construya de la forma más eficaz para lograr un propósito. En la medida en que la rima se comporte como un elemento auxiliar para conseguir el fin pretendido será valiosa, pero se convertirá en un estorbo si por el contrario, debido a su espectacularidad, acaba siendo una barrera para alcanzarlo.

Aunque Wilson se refiera fundamentalmente a himnos religiosos y piezas de oratoria, la desconfianza que inspira la rima en ese respecto se extiende también, en otros autores, al terreno de la escritura poética. Sidney, por ejemplo, se queja de que no ha visto "sino unas pocas obras impresas que tengan nervio poético", ya que la versificación oculta muchas veces "una maraña de palabras con una rima tintineante apenas acompañada de sentido" (SIDNEY, 2003: 177). De la misma forma que antes se aludía al tañido de las campanas, el tintineo aparece ahora como cifra de la musicalidad vacua.

En el original inglés, Sidney lo formula - a tingling sound of rhyme, barely accompanied with reasons- aludiendo a una frase hecha recurrente en aquella época y que ha perdurado hasta nuestros días. En casi todas las obras que estamos comentando y en numerosos poemas líricos y dramáticos de este período aparece la expresión "neither rhyme nor reason", tal cual o con variaciones. Esto, que equivaldría a las expresiones españolas 
"sin ton ni son" o "sin pies ni cabeza" -si los pies fueran métricos sería una traducción excelente-, se refiere a una acción que carece de sentido, de método y de propósito. En general se usa al margen de todo contexto literario pero, evidentemente, los poetas y los tratadistas no podían dejar de explotar, tanto en creaciones poéticas como en sus disquisiciones sobre la versificación, las implicaciones de su sentido literal, y lo convierten en un lugar común. Shakespeare usa variantes de la expresión en, al menos, cinco de sus obras - todas ellas comedias-, y en alguna de ellas incluso más de una vez. La utiliza con valores humorísticos o enfáticos en Como gustéis, en Las alegres comadres de Windsor o en La comedia de los errores. En general, es frecuente que se adopte la frase como excusa para señalar la divergencia, cuando no la oposición, entre ambos conceptos, razón y rima. Dentro de la obra de Shakespeare, es lo que sucede en Los dos hidalgos de Verona, cuando uno de los dos hidalgos, Valentín, habla con su criado (SHAKESPEARE, 1967: 269):

VALENTÍN: ¡Eh, amigo! ¿Qué estáis haciendo ahí razonando con vos mismo?

SPEED: No, yo estaba rimando; la razón es solo vuestra.

En la primera escena de Trabajos de amor perdidos, el caballero Berowne hace una afirmación que se antoja absurda según el hilo de la conversación; otro caballero, Dumaine, le pregunta que a qué viene su comentario, y se sigue el siguiente diálogo (SHAKESPEARE, 1986: 318):

BEROWNE. Fit in his place and time.

DUMAIN. In reason nothing.

BEROWNE. Something then in rhyme.

La humorada es clara, pero también la crítica implícita: a veces la rima puede condicionar el discurso, haciendo que el poeta introduzca despropósitos por su sola exigencia. No hace falta recordar que se trata de una preocupación añeja y que perdurará mientras existan la rima y la reflexión sobre la misma. Ya un siglo antes de todas estas obras y disquisiciones, lo había señalado 
Nebrija, en el capítulo sexto del segundo libro de su Gramática -"lo cual hacen los que usan de consonantes en las cláusulas de los versos, que dizen lo que las palabras demandan, y no lo que ellos sienten" (1989: 158)- y un siglo más tarde lo diría Boileau (1873: 144) -Que toujours le bon sens s'accorde avec la rime"-. Aunque es algo que aparece expuesto en varios de los tratados teóricos, también los propios escritores se quejan en ocasiones de que la rima imponga el uso de una palabra que, en principio, no formaba parte del plan de la obra.

Shakespeare, además, se queja también del efecto contrario, de lo que sucede cuando el poeta quiere emplear una palabra para la que no encuentra consonancia; lo hace dentro de la trama de otra de sus obras, Much ado about nothing, donde el enamorado Benedick interrumpe la canción que está entonando y se lamenta, no sólo de las penas de su amor, sino de las penalidades que le inflige la necesidad de rimar. Alude entonces a otros célebres amantes, como Leandro y Troilo, que, aunque sufrieron igual que él por causa del amor, "todavía caminaban tranquilamente por el camino llano del verso blanco". Él, sin embargo, cuando trata de expresar su amor, no encuentra otra rima para lady que baby -"una rima inocente", apunta-, horn para scorn -"una rima dura"-, fool para school -"una rima balbuceante"-. Y concluye: "muy ominosas terminaciones: no, yo no nací bajo el influjo de un planeta rimador" (SHAKESPEARE, 1986: 634).

El peligro de que la consonancia imponga sus exigencias y fuerce al poeta a decir lo que de otro modo no habría dicho es uno de los principales motivos para que Campion la rechace y condene, y da lugar a alguno de sus ataques más feroces: "Pero hay todavía otra falta en la rima del todo intolerable, la cual es que obliga muchas veces a un hombre a abjurar de su asunto, y extender un concepto breve más allá de todos los límites del arte" (2004: 284). Compara al poeta que usa la rima con el bandido Procrustes, que tendía a sus víctimas en un lecho y, en la medida en que su estatura no se acomodaba al mismo, los mutilaba o los descoyuntaba hasta hacerla coincidir. Acto seguido lanza el siguiente desafío: "Traed ante mí ahora a cualquiera de los rimadores con mayor autoestima, y dejadme ver si es capaz de leer sin sonrojarse sus rimas cojas y vacilantes". 
El de la rima como impulso que se impone al poeta y lo guía por donde su propia voluntad no lo habría llevado es un argumento recurrente y un obstáculo grave que deben solventar sus defensores. El propio Daniel, abogado de la rima, reconoce explícitamente que "la medida y la rima no son sino la base o el asiento sobre el que se levanta el trabajo que las inspira" y que ningún espíritu juicioso y respetable se quedará en la parte exterior de las palabras, entretenido con el sonido (2004: 230).

Otro autor que muestra su preocupación por la manera en que las exigencias formales de la rima pueden interferir de manera negativa con el pensamiento expresado es George Gascoigne, que en 1575 publica Certain notes of instruction concerning the making of verse or rhyme in English, un texto breve en el que aconseja al poeta sobre varios asuntos relativos a la versificación, tales como el orden de las palabras, la disposición de los acentos, el empleo de la cesura o determinadas licencias poéticas. Entre las recomendaciones sobre el uso de la rima encontramos la siguiente prevención -en la que otra vez aparece la expresión rhyme without reason- (2004: 242):

"Yo te exhortaría también a tener cuidado con la rima sin sentido. Mi intención, al decir esto, es que tu rima no te aparte de tu primer designio, porque muchos escritores, cuando ya han establecido los cimientos de su invención, todavía son arrastrados a veces por la rima hasta olvidarlos, o cuando menos a alterarlos, como cuando no pueden encontrar prontamente una palabra que pueda rimar con la primera (y continuar así su determinado designio); entonces ellos, o bien lo echan a perder con una palabra que rime (sin importar cuán poco sentido acarree), o bien cambian la primera palabra y así tal vez desvían o enturbian su invención anterior".

Lo preferible, sostiene Gascoigne, es que siempre se mantenga la primera determinación, e insiste en que hay que perseguir la palabra adecuada hasta lo más recóndito del pensamiento antes que "cambiar el buen sentido por una rima embarullada". Acto seguido ofrece unos consejos de tipo práctico que encuentra útiles para evitar estos problemas. Recomienda que el poeta tome la última palabra del primer verso y haga un recuento en orden 
alfabético de todas las palabras con las que comparte sonidos, lo que ejemplifica con un supuesto verso que acabara en care y que rimaría con bare, clare, dare, fare... -Webbe retoma más tarde la sugerencia y sustituye el ejemplo: brooke, crooke, hooke, looke... (1870: 64)- De esta idea y del método propuesto se burlará poco después Sidney en su Defensa de la Poesía, cuando expone los que considera mayores males de la forma poética y del estilo y se queja de que, a veces, la elocuencia aparece disfrazada "con la repetición de una letra, como si estuvieran obligados a seguir el método de un diccionario" (2003: 184).

También relativa a las iteraciones fónicas que constituyen la rima o la aliteración, aunque mucho más violenta, es la crítica que aparece en el prefacio de The Shepheardes Calender, obra de Edmund Spenser compuesta de doce églogas que se publicó de forma anónima en 1579, dedicada precisamente a Sidney. Dicho prefacio, en forma de epístola dirigida a su amigo Gabriel Harvey, aparece firmado por E.K., cuya identidad real es aún desconocida, aunque predomina entre la crítica la creencia de que corresponde al propio Spenser. Sea él mismo o alguien de su entorno, su ataque es feroz: "Desprecio y escupo sobre la tendencia viciosa de nuestros andrajosos rimadores (pues así suelen ellos mismos andar a la caza de la letra)" - la aclaración del paréntesis se debe a que en el original utiliza de manera paródica el mismo procedimiento que critica: "rakehellye route of our ragged rymers" (SPENSER, 1890: 40). Hay una carta de Harvey a Spenser -impresa y publicada ya en 1580- en la que puede observarse otra burla acerca de este uso; se refiere el primero a las cartas del segundo como "long, large, lavish, luxurious, laxative letters", y se interrumpe a sí mismo: "pero, en el nombre de Dios, ¿cuándo jamás en mi vida he ido a la caza de la letra antes?" (HARVEY, 1815: 296). La expresión "ir a la caza de la letra" -con sus variantes, course o hunt- se utilizaba en aquel tiempo sobre todo para referirse a quienes abusaban de la aliteración -si bien la crítica ha destacado en varias ocasiones que, pese a sus afirmaciones al respecto, tanto Spenser como Sidney solían emplearla-, algo que, como ya se ha visto, se tenía en muchos casos por falta del poeta, aunque ese rechazo se hace extensible en ocasiones a la rima. También se verá más tarde, 
por otro lado, que Spenser, Sidney y Harvey tenían el propósito común de renovar la métrica inglesa, procurando un renacimiento de los modelos latinos en donde la rima no tenía cabida.

Aunque no de una manera tan didáctica ni con un propósito explícito de orientar a los poetas como en el caso de Gascoigne, en el conjunto de las obras que estamos analizando es fácil encontrar un considerable número de opiniones en torno a la estilística de la rima, unas veces con cierta vocación preceptiva y otras como simple reflexión o contribución desapasionada al debate. En el caso de Puttenham, por ejemplo, predomina la censura de las malas prácticas. El capítulo noveno del libro tercero de su Arte de poesía inglesa lleva un título suficientemente claro y al que poco más hay que añadir: "De cómo el buen creador no forzará sus palabras para ayudar a su rima, ya sea mediante la falsificación de su acento o mediante falsa ortografía" (2003: 122). Al desarrollar la idea, Puttenham sostiene que el poeta no puede caer en la dislocación acentual ni cambiar la ortografía para favorecer la rima porque, sobre todo, eso indicaría que "tal creador no posee un vocabulario copioso en su propio idioma", y que no es maestro de su oficio. Con todo, concede que antes que dejar al oído una impresión ingrata, es preferible modificar la ortografía, y lo ejemplifica con un hipotético uso de la palabra "doore" ('puerta'), que debería, llegado el caso, escribirse "dore" si quisiera rimarse con "restore" (1811: 67).

Añade Puttenham que la gracia principal de la poesía en lengua vulgar reside en la sinfonía -otro nombre para la rima-, y que el poeta no debe tomarse demasiadas licencias en cuanto a la concordancia de sonidos - concords-, porque en tal caso "el creador no es en verdad sino un chapucero, y no un poeta". Y pone como ejemplo general de la mala práctica a los antiguos rimadores, y como caso particularmente escandaloso el de unos versos de su contemporáneo George Turberville en los que la palabra inglesa ioy (joy) rima con la francesa Roy (roi), pese a que su pronunciación no puede estar más alejada. Cabe discutir si se trata de un ejemplo de eye rhyme. Dado que el conocimiento empírico de la pronunciación de la época está fuera de nuestro alcance, ni los filólogos ni los críticos se ponen de acuerdo sobre la índole de este tipo de rima, considerado como tal desde 
una perspectiva moderna pero que tiende a justificarse con el argumento de que, en su origen, la pronunciación de las palabras en posición de rima era coincidente -si bien tal coincidencia se suele deducir, precisamente, de esa presunta rima-. Es muy significativa, por lo tanto, la queja de Puttenham en este sentido y su rechazo a la utilización de palabras que comparten grafías pero no sonidos.

Otra práctica que Puttenham desaconseja, en cuanto al uso de la rima, es el empleo de la que Rudolf Baehr (1989: 69) 1lama rima intensa -término que aceptan y recogen Devoto (1995: 110) y Domínguez Caparrós (1999: 332); Pietro Beltrami la llama rima ricca (1994: 51), si bien por rima rica puede entenderse también aquella que resulta novedosa y sorprendente (TORRE, 2000: 57)-; rima intensa, pues, sería aquella en la que la coincidencia de sonidos incluye alguno de los que preceden al último acento. Puttenham precisa que, pese a lo dicho de que para hacer una buena rima "los versos deberían tener cadencias similares", en su opinión "debe haber alguna diferencia”. Así, constrain y restrain, o aspire y respire, no formarían una buena concordancia porque son prácticamente la misma cosa, dice él, pero si se cambia algún sonido -aspire, desire, retire-se resuelve el problema. Concluye con otra reprimenda: "esta regla, no obstante, no es bien observada por muchos creadores, por falta de buen juicio y de un oído delicado" (2004:122).

También se declara Puttenham en contra de que se utilice la rima en el medio y el final de un mismo verso. Lo dice en un tono entre doctoral y burlón (2004:124):

"Nota también que no es recomendable utilizar la rima o concordia al mismo tiempo al final y en el medio de un verso, salvo que se trate de naderías y poemas triviales, porque ello muestra una cierta ligereza, ya sea del asunto o de la cabeza del creador, aunque estos rimadores comunes lo usan mucho".

Dentro de lo que se puede llamar estilística de la rima, también se reflexiona sobre el uso de palabras agudas, llanas y esdrújulas en posición final. Dice Puttenham (2004: 121) que 
"esta cadencia es la caída de un verso en la última palabra con un cierto sonido armonioso, que al ser contrastado con otro de sonido similar produce una concordancia. Y la cadencia toda está contenida a veces en una sílaba, a veces en dos, o en tres como máximo. Porque más allá de la antepenúltima no alcanza el acento (que es la principal causa de la cadencia)".

No obstante, encuentra una excepción -que califica como "usurpación"- cuando se otorga una pronunciación sobresdrújula a palabras como honourable, matrimony, por ejemplo. Entre las otras tres posibilidades, Puttenham encuentra más satisfactoria la terminación aguda, "más dulce y recomendable"; cuando el acento recae sobre la penúltima sílaba, la rima se hace "más ligera y no tan placentera", pero "la caída sobre la antepenúltima es la más desagradable de todas, porque hace tu metro demasiado ligero y trivial, y es más adecuada para el poeta epigramático o cómico que para el lírico y elegíaco" (2004: 122).

También Sidney, muy al final de su ensayo (2003: 189-190), habla de las tres terminaciones, introduciendo en el inglés la terminología francesa de rimas masculinas y femeninas, a las que se añade el término italiano sdrucciola. Dentro de su pequeño ejercicio de comparación, señala Sidney que los italianos no emplean la rima aguda, ni los franceses la esdrújula, en tanto que los ingleses utilizan las tres. El autor pone ejemplos de todas ellas, pero no hace ninguna valoración al respecto; añade que es mucho más lo que podría decirse sobre ello pero que no quiere extenderse en demasía.

Harington alude a esta descripción de Sidney -de cuya Defensa de la poesía, aún inédita, poseía una versión manuscrita-, aunque le reconoce una autoridad aún mayor a su carácter ejemplar como poeta, y destaca la dificultad añadida del modelo que Sir Philip defiende. La reflexión de Harington se produce en un contexto muy preciso: la explicación y defensa en 1591 de su traducción de Orlando furioso en un prefacio que luego se publicaría de manera independiente como A Brief Apology of Poetry. En él, el traductor defiende una serie de elecciones técnicas y estilísticas tanto del narrador como de la traducción, hasta que llega al asunto de la rima. Reconoce haber recibido 
algunas críticas por el empleo excesivo de rimas bisílabas y trisílabas -esto es, graves y esdrújulas-; esto demuestra, una vez más, que el gusto inglés se inclinaba claramente hacia la rima aguda (1815:143). Lo que responde Harington a tal censura es que era ciertamente más fácil rimar a la manera antigua, con las solas dos posibilidades de la rima, de modo que un verso que terminaba con "civillitie", dice él, podía rimar con palabras como "see", "flee" o "decree", y además de no conceder ningún valor a una oposición que carece de argumentos y que es mera cuestión de gusto, se remite a su admirado Sidney: "pero para contestar a esto en una palabra, y conseguir que se queden tranquilos en este respecto: Sir Philip Sidney no sólo las usaba, sino que las apreciaba"; y, acto seguido, toma de él algunos ejemplos que, en varios casos, incluso implican a dos palabras en la rima, como "shamed is", "named is" y "blamed is", o "hide away" y "bide away" (1815: 145). En cuanto a las rimas femeninas, aduce que son aprobadas por otras lenguas y que los franceses las tienen por las más dulces.

Daniel no hace casi ninguna alusión a las rimas esdrújulas -salvo para señalar lo antinatural que le parece su conversión en agudas por motivos rítmicos-; sí se refiere con más demora a las terminaciones masculinas y femeninas y señala ciertas directrices para su empleo y combinación, como que las rimas femeninas no son adecuadas para los poemas épicos, aunque concluye que todo el asunto, en realidad, compete a los gustos y depende de las modas, que siempre se encuentran en perpetuo cambio, por lo que no cree pertinente hablar de corrección o incorrección.

Otras recomendaciones que se suelen hacer sobre el uso y la estilística de la rima tienen que ver con la adopción de un determinado esquema en la estrofa, con su relación con lo genérico o con la separación que se considera más adecuada entre los versos que consuenan.

Por ejemplo, Daniel, pese a su defensa general de la rima, reconoce lo siguiente: "debo confesar que, para mi propio oído, esas cadencias constantes de pareados usadas en poemas largos y seguidos, son muy cansadas y enojosas". Dice entonces que, para evitar la "sobresaturación del oído con ese siempre cierto y 
pleno encuentro con la rima", ha experimentado en algunas de sus epístolas con la alteración del orden, haciendo que la rima no se establezca con el verso inmediato. Como en el caso anterior, Daniel se inclina casi siempre por la variación o por la variedad, y por ello es de la opinión de que los mejores sonetos son aquellos que, frente al modelo italiano, tienen rimas distintas en cada cuarteto (2004: 215).

También considera Daniel que hay una relación entre el tipo de rima que se emplea y el género al que pertenece la obra. Si antes se ha visto cómo algunos autores establecían una correspondencia entre la obra épica y el verso agudo, Daniel la establece entre la tragedia y el verso blanco. En una de las raras concesiones a Campion, su oponente reconocido, sostiene: "Y debo confesar que mi adversario ha provocado esto en mí, que creo que una tragedia, en el fondo, se conforma mejor con el verso blanco y excusa la rima, salvo en el coro o cuando una sentencia requiere un pareado" (2004: 231). Puede reconocerse, pues, cierta correspondencia entre la rima y el género del discurso, y ciertas asociaciones entre la forma y el contenido, puesto que, incluso dentro de una tirada en verso blanco, Daniel propone que los enunciados de carácter gnómico o que transmitan una idea con especial gravedad se expresen mediante la rima. Cabe pensar, por una parte, que la rima les dará un relieve especial dentro de su contexto, y, por otra, que tales enunciados se ajustarán así mejor a la costumbre de utilizar la rima en proverbios y refranes, formas expresivas que también tienen el propósito de almacenar y transmitir el saber.

Otra cuestión que se plantean los teóricos es la distancia idónea entre las rimas. Puttenham es, con diferencia, quien más importancia otorga a este asunto, $\mathrm{y}$ en su The Art of English Poesy incluye una numerosa serie de representaciones gráficas que reflejan los posibles esquemas de la rima en diferentes estrofas. Justifica esos diagramas por motivos didácticos, y también mediante un dudoso y algo extravagante argumento basado en la correspondencia entre los sentidos porque, según él, la proporción visual "declara la naturaleza de lo audible"; si algo complace al oído, "lo mismo representado mediante un diagrama para la vista complacerá al ojo también, y viceversa, y esto es por 
una simpatía natural entre el oído y el ojo, y entre melodías y colores" (2004: 126). En todo caso, es una forma útil de señalar el esquema de la rima y relativamente habitual entre los poetas de entonces, dado que todavía no se usaba la notación alfabética a la que hoy estamos acostumbrados.

Puttenham, apoyándose en los mencionados diagramas, explica que las distancias observadas habitualmente para rimar serían de entre uno y cuatro versos - esto es, el primer verso de una estrofa rimaría con el segundo o con el quinto, respectivamente-, aunque, si éstos fueran muy cortos, podría ampliarse a una distancia de cinco o seis. La primera distancia, sigue diciendo, es para los pareados, el esquema que sería más popular y donde los versos se suceden rápidamente con el continuo retorno de la rima "de modo que su música nunca se pierde, ni escapa del oído, un pareado sucediendo a otro tan cerca y tan repentinamente" (2004: 127). La segunda distancia es la que, saltando el intermedio, se establece entre los versos primero y tercero; es la que se conoce como rima cruzada. En la tercera distancia riman el primero y el cuarto, y señala Puttenham que los versos que quedan en el interior pueden establecer sus respectivas rimas con esa misma distancia o bien, si así se prefiere, de otro modo distinto; se trata, se nos dice, de "una manera no tan común, pero suficientemente placentera y permisible" (1811: 71). Las distancias mayores serían, según Puttenham, más raras y artificiales, y apropiadas sólo para los versos cortos.

Habría casos especiales, sin embargo -los sigue ilustrando con nuevos diagramas, no recogidos en la reciente edición de Alexander-, que pueden llegar a abarcar una distancia de ocho, diez o doce versos. Según se nos explica, estas rimas tan distantes sirven para hacer que la canción sea proporcionada y tendrían como principal cometido dar cohesión a las estancias, de las que constituirían el límite y que, si no fuera por estas rimas distantes, aparecerían como algo fragmentario -como pasaría, explica y lo representa gráficamente, si en una estancia de doce versos la rima se organizase en tres cuartetos-. Concluye Puttenham que todo cuanto puede objetarse contra esta amplia distancia es que el oído podría perder un tanto la noción de la rima, pero eso le sucedería sólo “al oído rudo y popular, pero no al cultivado, y en 
este sentido el poeta debe saber para quién hace su rima, y acomodarse a ello", y no ofrecer a un oído bárbaro la misma música que ofrecería a un oído delicado (2004: 128).

Más interesante que las ideas concretas en sí, lo significativo en este respecto es la evidencia de que la rima desempeña un papel esencial en la estrofa y, por lo tanto, en la estructura del poema. Recuérdese, en este sentido, cómo afirma Cornulier que la característica definitoria de la estrofa frente al verso es la rima, y que la noción de superestructura métrica implica que la rima es la terminación de algo (1995: 130).

En resumen, en el conjunto de estas recomendaciones y dictámenes sobre el uso de la rima se puede advertir la influencia y la confluencia de consideraciones relativas a la eufonía del verso -donde entra en juego, fundamentalmente, el gusto personal del comentarista-, a la estructuración del texto -la rima sería el elemento vertebrador de la estrofa-, a las convenciones genéricas -que establecen, con frecuencia, una relación entre la cualidad de la rima y la índole del asunto tratado- y, por último, a cuestiones pragmáticas -teniendo en cuenta, como acaba de verse, las expectativas del lector, que a su vez pueden depender de su formación y su clase social-. A todo esto, además, habría que añadir otro tipo de consideraciones: los autores de la época son conscientes de que el empleo de la rima está condicionado por las características de la lengua inglesa.

Existe una clara conciencia de que cada lengua tiene sus propias características. Más allá del dominio de la prosodia, que tan determinante resulta en todo cuanto atañe a la métrica, pueden darse peculiaridades fonológicas y morfosintácticas que provocan que lo que en una lengua pueda hacerse con naturalidad, en otra contravenga las inclinaciones del buen gusto.

En lo tocante al asunto que ahora nos ocupa, la rima, también cabe encontrar distintas consideraciones que tienen en cuenta las características idiomáticas del inglés. Y se hace, con frecuencia, incluyendo una cierta perspectiva o voluntad comparatista. Si bien, como ya se ha dicho en otra parte, resulta prematuro hablar de comparatismo en una época en la que se comparte una misma y única poética, la clasicista, que además tiene una clara vocación de universalidad, es precisamente en el campo de la 
métrica -y gracias en gran medida a la diversidad que impone la diferencia entre las lenguas- donde con mayor facilidad se emplea la comparación (FRAU, 2003: 261-264).

Unas páginas más atrás se ha recordado cómo Sidney comparaba el uso de las rimas agudas, llanas y esdrújulas en la poesía inglesa, francesa e italiana. Puttenham también hace referencia a las particularidades de la rima inglesa, cuando señala lo inadecuado y desagradable de utilizar en posición de rima palabras muy largas, que en otras lenguas son habituales; por más que el poeta sea libre de "rimar con palabras de toda condición, sean ellas de muchas sílabas o de pocas", dice Puttenham, habría una elección más recomendable, "puesto que hay algunas palabras de una excesiva longitud, que han sido traídas de un latín pretencioso o tomadas como préstamos de extranjeros, y su uso en la rima no es nada placentero" (2004: 123).

Ya unas líneas antes se había lamentado de la mala influencia de algunas traducciones latinas y francesas, que habrían ayudado a introducir ciertas licencias perniciosas en el uso de la rima. Pero el convencimiento de que las palabras polisílabas no convienen en posición de rima tiene su origen en las características que observa en la lengua inglesa. Después de definir la rima y describir el placer que comporta la percepción del sonido que retorna, Puttenham añade: "y para este propósito sirven excelentemente bien los monosílabos de nuestro inglés sajón, porque ellos reciben cualquier acento natural e indiferentemente, y en ellos, si terminan el verso, descansa el necesario acento agudo, y eso no sucede al final de cualquier palabra bisílaba o polisílaba" (2004: 120). Sería, por lo tanto, la mayor flexibilidad rítmica la que haría aconsejable el uso de los monosílabos, más fáciles de integrar en cualquier lugar del verso pero, sobre todo, menos conflictivos en la zona de la rima.

El autor, en todo caso, admite que todas estas preferencias son sutilezas que sólo aprecia el conocedor que ha educado bien su gusto. Integrado en círculos aristocráticos y de refinada cultura, desprecia lo popular y lo manifiesta con cierta frecuencia - puede observarse también cómo critica, esta vez en su acepción de composición poética, las "rimas de taberna"-. Ya se ha visto antes cómo Puttenham se quejaba de que los oídos poco 
cultivados no son capaces de apreciar las rimas cuando entre ellas media una cierta distancia, y de nuevo arremete contra los gustos populares al señalar que, para la gente común, la mayor valía y adecuación a la estructura de la lengua inglesa de aquella rima que se basa en palabras monosílabas pasa desapercibida; el motivo es que sería gente (2004: 123)

"que se complace mucho en asistir a representaciones teatrales y entremeses y, más allá de su natural ignorancia, tiene todo el tiempo y en tal medida los oídos atentos al asunto y los ojos puestos sobre lo que se muestra en el escenario, que prestan muy poca atención a la sutileza de la rima, y, por lo tanto, se da por igual de satisfecha con aquella que es grosera como con cualquier otra más fina y delicada".

Pero, volviendo a los asuntos de la comparación y a la conciencia de que la lengua inglesa tiene sus características específicas, la mayoría de los autores recurre a estos argumentos, por otra parte obvios, para explicar las necesarias diferencias estructurales que hay entre el verso latino, fruto de un sistema cuantitativo, y el verso inglés, por más que alguno se resista -igual que ha sucedido esporádicamente en otras tradiciones, como la española o la italiana- a admitir que en la lengua inglesa no hay sílabas breves y largas. Roger Ascham se lamenta de que el inglés, "que usa principalmente palabras de una sílaba, que habitualmente es larga", no se adapta bien al ritmo dactílico, que según él es el más apropiado para el Carmen Heroicum (1898: 289). Asimismo, Thomas Campion, uno de los máximos detractores de la rima y vindicadores de la versificación clásica, reconoce, a su pesar, la dificultad de adaptar la métrica latina a la lengua inglesa: "Las viejas costumbres, si son mejores, ¿por qué no habrían de restaurarse?, como el todavía floreciente hábito de la poesía numerosa utilizada entre los romanos y los griegos. Pero la inadecuación de nuestras lenguas nos desalienta" (2004: 283). Su añoranza por esa versificación numerosa le lleva más adelante a formular una suposición aventurada, otra vez dentro de una perspectiva supranacional (2004: 284): 
"Si a los italianos, franceses y españoles, que con ánimos han compuesto en rima, se les preguntara si prefieren que los libros que han publicado (si su idioma lo permitiera) permanecieran como están, en rima, o se trasladaran a los números antiguos de los griegos y romanos, ¿no responderían que "en números"?"

Daniel contesta a su adversario utilizando, por el contrario, un sólido argumento: el de que un autor como Petrarca escribió tanto prosa y verso latinos como verso en el italiano vulgar, y si escribiendo en latín mostró su excelencia, lo que le condujo a la gloria y la fama fue su obra en la lengua materna, que sus compatriotas "aprecian sobre todo lo que cualquier ingenio podría haber inventado en cualquier otra forma que aquella en la que está, que sin lugar a dudas ellos no cambiarían por las mejores medidas que griegos o latinos puedan mostrarles" (2004: 218).

No puede entenderse el debate sobre la rima si no se tiene en cuenta el contexto en que éste se incluye, que es la defensa de los metros clásicos frente a los modernos o al contrario. Es cierto que algunas de las críticas y defensas concretas que se hacen de la rima, acaso las de mayor interés, se centran en sus cualidades intrínsecas y se mantienen al margen de la otra disputa, pero, en su mayor parte, las razones que se dan contra la rima tienen el propósito fundamental de desprestigiar el verso vernáculo. Una de las características del debate sobre la rima es que se trata de un asunto en el que no pueden servir de guía ni de modelo - por razones evidentes- los autores grecolatinos, salvo por alguna alusión a la similicadencia. En este caso, más que la poética clásica, está presente la sombra de la poesía clásica, modelo a veces añorado.

Detenernos por extenso en ese otro debate nos desviaría de nuestro propósito inicial y de los límites que nos hemos marcado, de manera que baste recordar que hay una serie de tratadistas de la época, como Ascham, Webbe o Meres, que reivindican la superioridad del verso cuantitativo escrito a la manera latina y que, en consecuencia, rechazan el verso silábico-acentual que se está imponiendo desde Henry Howard y Thomas Wyatt y que suele utilizar la rima. También varios poetas tienen el propósito 
común y explícito de lograr la sustitución de la rima por el metro, esto es, de sustituir el verso rimado por otro basado en la cantidad al modo clásico. Algunos de estos poetas formaron poco antes de 1580 una especie de círculo literario e intelectual al que llamaron el Areópago, cuyo núcleo estaría formado por Sidney, Spenser y Harvey -los dos primeros con mayor reputación y talento, el último con más empeño y vocación de polemista-, y en el que participarían otros poetas como Edward Dyer, Fulke Greville, tal vez Daniel Rogers. Harvey, que llegó a manifestar su voluntad de que en su epitafio se le recordara como inventor del hexámetro inglés -lo que le acarreó alguna que otra burla- se felicita en una de sus cartas a Spenser porque "esos dos excelentes caballeros, Mr. Sidney y Mr. Dyer" han "contribuido a nuestra famosa empresa para cambiar las bárbaras y farragosas rimas por el verso con artificio" (1815: 264). Spenser le responde que ambos, Sidney y Dyer, "han proclamado en su Areópago un cese y silencio de los simples rimadores" y "han prescrito ciertas leyes y reglas sobre las cantidades de las sílabas inglesas" (1815: 288).

No obstante, pese a este entusiasmo inicial, Spenser no tardó en darse cuenta de lo quimérico de su propósito, y también Sidney hubo de comprender que la propuesta de un verso cuantitativo no era compatible con las características de la lengua inglesa. La voluntad restauradora y los intentos de implantar un "verso inglés reformado" son pronto abandonados por los integrantes del Areópago y, en rigor, no se puede decir, sin más, que todos estos poetas estaban en contra de la rima, dado que ésta predomina ampliamente en el conjunto de su obra; lo cierto es que sólo durante un periodo concreto y limitado emprendieron una especie de aventura estimulante, que resultaba atractiva con su aire conspiratorio y que supuestamente era noble y aristocrática en su vocación de rescatar lo mejor de una época venerada, pero que, al fin y al cabo, no dejaba de ser eso, una aventura, y que, como se ha dicho y como ellos mismos asimilaron pronto, resultaba descabellada por múltiples razones.

En cuanto a los teóricos que destacaron en su persecución y condena de la rima, podemos citar, por ejemplo, a Roger Ascham, autor de The Scholemaster (1570), célebre tratado sobre 
la educación donde se afirma que la lengua inglesa "también puede recibir la correcta cantidad en las sílabas y un verdadero orden de la versificación, como el griego y el latín, si un hombre diestro se encarga de ello" (1898: 150). El vínculo de esta propuesta con los textos clásicos es evidente y se refleja en que varios de los principales textos aducidos como ejemplo exitoso de su aplicación son traducciones de los originales griegos y latinos. Así, Francis Meres, en su obra Palladis Tamia-subtitulada A comparatiue discourse of our English Poets, with the Greeke, Latine, and Italian Poets, publicada en 1598 y citada habitualmente como uno de los antecedentes ilustres del comparatismo (también podría verse, según su contenido, como una propuesta de canon)-, destaca que "Consaluo Periz, ese excelente hombre de letras y Secretario del Rey Felipe de España, al traducir el Ulises de Homero del griego al español, ha evitado con buen juicio el error de la rima, aunque no alcanzó plenamente la verdadera y perfecta versificación" (1815: 149). Gonzalo Pérez -padre de Antonio, también secretario de Felipe II- había dado a la imprenta su versión de la Odisea en 1550. A juicio de Meres, sin embargo, sí alcanza esa perfección Henry Howard, conde de Surrey, en su traducción del cuarto libro de la Eneida-hecha en verso blanco, del que Howard es considerado el introductor en Inglaterra-. Ascham, a su vez, se congratula de que el sienés Felice Figliucci, comentarista de Aristóteles -al que considera representante en aquellos días del buen juicio en Italia y que escribe, según él, en un excelente italiano- realice una "honesta invectiva contra la tosquedad de la rima en los versos de esa lengua", y elogia el hecho de que cuando traduce ejemplos de Homero o de Eurípides lo hace "no siguiendo las Rimas de Petrarca, sino en tal perfecta clase de verso, con semejantes pies y cantidad en las sílabas, como él encuentra en la lengua griega" (1898: 294).

Sin embargo, pese a la opinión de Ascham y Meres, también hay traducciones de obras grecolatinas que optan por el empleo de la rima, como la que de la Iliada comienza a hacer George Chapman en 1598. En el poema introductorio, "Al lector" -también en verso rimado-, Chapman reflexiona muy de pasada sobre la rima, incidiendo en algunos de los aspectos que ya se han 
visto. Para justificar su uso en la traducción, dice de la rima que "arranca una suave melodía para el oído con gran naturalidad". Luego recurre a un argumento ya comentado anteriormente: afirma que "nuestros monosílabos caen con tal gracia / y se reúnen, opuestos en la rima, como si se besaran"; por el contrario, "italiano y francés son más amétricos, / sus demasiadas sílabas en áspera colisión / caen como si se rompieran el cuello" (CHAPMAN, 1888: LXXX), prosigue burlón, jugando con el doble sentido de caída.

Otro autor que, como se ha dicho, lleva a cabo algunos intentos de adaptar el verso latino -quizás sea quien lo hace con más fortuna- es Sidney, quien, no obstante, no se decanta por la superioridad de ninguno de los dos: el antiguo, cuantitativo, le parece "más adecuado para la música" y "para expresar con viveza las diversas pasiones por medio del sonido grave o agudo de cada sílaba debidamente medida" (2003: 188); el moderno, cuyo "principio vital reside en el sonido semejante de las palabras, que llamamos rima", "trae al oído cierta musicalidad" y al final logra el mismo resultado, "teniendo los dos melodía y no careciendo ninguno de majestuosidad" (2003:189). También concluye Sidney que el inglés se adapta a ambos modelos mejor que cualquier otra lengua vulgar, por una serie de características lingüísticas que perjudican a lenguas como el francés, el alemán, el italiano o el español.

Los mencionados intentos de introducir en la poesía inglesa un verso a la manera latina se suceden con resultados muy desiguales -aunque en su mayoría fallidos- aproximadamente durante una década, al menos a partir de 1577, y decaen en los años noventa, de modo que cuando Thomas Campion entra en escena su postura sobre la versificación resulta completamente extemporánea. Él, por lo demás, es consciente de que su lucha está prácticamente perdida de antemano, y lo reconoce de manera explícita (2004: 282): "No ignoro que cualquiera que por la vía de la reprensión examine las imperfecciones de la rima ha de contender con muchos enemigos ilustres, y muy expertos." Añade que "ha crecido una suerte de prescripción del uso de la rima, para impedir la corrección de los números verdaderos", y esto en muchas naciones, "contra lo cual parece algo casi 
imposible y vano contender", pero no se desanima: "todo esto y más no puede, sin embargo, apartarme de una legítima defensa de la perfección".

Con todo, la superación de ese enfrentamiento entre latinistas y defensores del verso silábico-acentual rimado no trae consigo una aceptación general y definitiva de la rima. Ésta seguirá percibiéndose con frecuencia como un obstáculo incómodo para la poesía y, como señala Donald Wesling, la disputa del verso cuantitativo contra la rima se convierte en la del verso blanco contra la rima (WESLING, 1980: 47). Destaca Wesling que el doble éxito de Shakespeare y de Milton, tanto usando la rima como sin usarla, se convirtió en un dilema para las generaciones posteriores. Se trata de una polémica que excede los límites cronológicos del período que estudiamos, y todavía en 1668 Dryden - abanderado del pareado heroico- afirma que la rima conviene a la poesía dramática, frente a la postura más escéptica, en ese sentido, de Milton (SYMONDS, 1895: 59-60). En todo caso, aunque también en el uso del verso blanco pueda pesar la consideración de que la rima es un elemento intruso que carece de la tradición clásica -argumento que se encuentra igualmente entre los poetas y teóricos españoles e italianos del Renacimiento-, los principales motivos suelen ser otros, alguno ya comentado como la supuesta dicotomía entre rima y razón.

La rima se había impuesto sobre el verso aliterativo con sorprendente rapidez en el siglo XIV - hay críticos que lo atribuyen fundamentalmente a las transformaciones lingüísticas de la época, que renuevan el léxico e incorporan un nuevo caudal de flexiones-, con Chaucer como figura principal del cambio. Pero en el siglo XVI, como se ha dicho, y dentro de la polémica renacentista que surge sobre la versificación, la rima llega a percibirse, por su novedad casi radical frente al verso clásico, como la negación del mismo, o como el estandarte más llamativo de los nuevos versos. Las críticas, en este sentido, son a veces furibundas. Ascham, por ejemplo, casi nunca utiliza la palabra ryming sin anteponer adjetivos como barbarous o rude; él y Francis Meres coinciden al usar la expresión "the fault of ryming". Éste último se refiere, despectivamente, a "the curiosity of rime", con lo que subraya su carácter anecdótico, prescindible $\mathrm{y}$, en último 
término, anómalo. En realidad, Meres (1815: 149) sigue aquí casi literalmente a William Webbe, que ya unos años antes había usado esa misma expresión en un contexto idéntico. Afirmaba Webbe que Pierce Ploughman -título de una sección de la obra del S.XIV que acabó por ser así conocida y cuyo autor parece ser William Langland- fue el primer poeta "que yo he visto que observó la cantidad en nuestro verso sin la curiosidad de la rima" (WEBBE 1870: 32). Webbe también emplea expresiones de desprecio contra la rima, tales como rude, balding, brutish -frente al true verse-; y contra los rimers, a quienes califica de "rústicos" o "andrajosos".

Todos estos autores coinciden en un argumento contra la rima, que dará ocasión a distintas réplicas por parte de quienes la defienden; nos referimos a la cuestión de los antecedentes, de la genealogía de la rima. Con un acusado sentido aristocrático, Ascham y Webbe o Campion - estos dos últimos siguiendo al primero-, no sólo subrayan que la rima carece de la nobleza de cuna de la prosodia grecolatina, sino que destacan que fue introducida por los destructores de esa cultura clásica. En cuanto a lo primero, coinciden en señalar que, como afirma Campion, pese a que en alguna ocasión aislada puede encontrarse algún vestigio de la rima -cita los Carmina prouerbialia- en la lengua latina (CAMPION, 2004: 283-4),

"los nobles griegos y romanos, cuyos elaborados monumentos sobreviven a la barbarie, se ataron a la estricta observación del número poético, abandonando así el cosquilleo infantil de la rima, que se imputó como gran error a Ovidio por publicar este verso rimado: Quot coelum stellas tot habet tua Roma puellas".

Su tesis es que la rima no existía en latín sino, como ya se ha mencionado, a la manera de una figura retórica a la que sólo muy espaciadamente y con precauciones se debía recurrir, so pena de recibir las críticas susodichas. En otras ocasiones se hace la salvedad de que ese posible antecedente de la rima que es dado encontrar entre los textos clásicos nunca se empleaba en el verso, sino sólo en la prosa. También tuvo éxito -es un error que 
repiten otros autores- la atribución que Ascham hace de la invención de la rima al poeta alejandrino Simias de Rodas, que en realidad fue un precursor del caligrama y de quien se conservan tres carmina figurata. Sin embargo, ni siquiera ese supuesto uso temprano aportaría el más mínimo prestigio a la rima, puesto que, según Ascham, se trató de una anomalía rechazada ya en su época: "fue en seguida condenada, y poco después los dos, autor y libro, olvidados también por los hombres, y devorados por el tiempo, de modo que a duras penas el nombre de ambos se guarda en la memoria del saber" (1898: 292-3).

Pero lo que les parece más grave a los detractores de la rima es que ésta habría sido introducida por los bárbaros que acabaron, según ellos, con la cultura clásica. Incluso Puttenham, que en general se muestra favorable al uso de la rima, explica cómo la invasión de hunos y vándalos provocó que la poesía métrica grecolatina se alterara y corrompiera, hasta el punto de que "los propios griegos y latinos se complacieron con los versos rimados, y los usaban como cosa refinada y excelente" y dejó de gustarles lo que no llevaba rima, ya fuera prosa o verso (2004: 6566). A partir de ese momento, Puttenham distingue una tradición culta, latinista y sin rima, frente al gusto popular, claramente inclinado hacia su uso.

Sobre este particular, Ascham dice recordar con agrado el tiempo que pasó en Cambridge y las charlas que allí sostuvo con otros hombres de letras sobre los poetas clásicos y la perfección que había alcanzado su poesía, y sobre cómo los ingleses deberían darse cuenta de la tosquedad de la rima (1898: 288),

"introducida primero en Italia por los godos y los hunos, cuando todos los buenos versos y la buena erudición fueron destruidos por ellos, y después fue llevada a Francia y Alemania, y, por fin, recibida en Inglaterra por hombres de excelente ingenio, ciertamente, pero de escasa formación y de menos juicio en ese respecto".

Webbe se remite a Ascham, del que reproduce con bastante fidelidad este último párrafo. Pese a esta acusación de barbarie y a la consideración de que la rima es una advenediza, los 
defensores de la rima no renuncian a encontrarle ilustres abuelos, o, cuando menos, una antigüedad similar o incluso mayor que la del verso clásico. Es lo que hace Puttenham, cuando afirma: "Pero los hebreos y caldeos, que eran más antiguos que los griegos, no sólo usaron una poesía métrica, sino también, con la misma, una especie de rima, como ha sido observado por los eruditos" (2004: 64). Aquí no importa tanto la exactitud de lo afirmado -el conocimiento de la métrica a la que alude era muy deficiente- cuanto la voluntad de encontrar antecedentes remotos para la rima. No conforme con el argumento de la antigüedad, Puttenham añade sobre éste el de la universalidad, como luego hará Daniel, y continúa diciendo: "De donde se desprende que nuestra poesía vulgar rimada era común a todas las naciones del mundo alrededor, a las que los latinos, y los griegos en particular, llamaban bárbaras". Unas líneas más adelante, basándose en los testimonios y descripciones de viajeros y navegantes, amplía el dominio de la rima a los aborígenes americanos -destaca a los peruanos- y dice que "incluso los caníbales cantan y pronuncian sus asuntos más elevados y sagrados en ciertos versículos rimados y no en prosa" (2004: 65). La conclusión a la que llega Puttenham es que todo esto prueba que esa manera de la poesía vulgar es "más antigua que la artificial de los griegos y latinos"; y que la rima deriva "del instinto de la naturaleza, que estaba antes que el arte o la observación". El de la universalidad es también uno de los principales argumentos en que Samuel Daniel basa su defensa de la rima (2004: 211):

"Y es ésta una melodía tan natural y tan universal que parece ser tolerada por todas las naciones del mundo, como una elocuencia legada que corresponde a toda la humanidad. La universalidad expone su fuerza general: porque si los bárbaros la utilizan, entonces ello demuestra que suena de manera agradable a las inclinaciones de los bárbaros; si las naciones civilizadas la practican, ello prueba que excita los corazones de las naciones civilizadas; si todas, entonces es que tiene un poder en su naturaleza sobre todas."

La postura de Daniel, que participa tangencialmente -como la de Puttenham- en el debate clásico sobre la relación entre ars 
y natura, subraya, por lo tanto, la universalidad de la rima, que justificaría sobradamente su utilización en la poesía inglesa o en cualquier otra. De hecho, Daniel procede a continuación a enumerar las distintas tradiciones que la usan; después de aludir a las lenguas eslavas y arábigas -con su expansión por partes de Asia y África-, dice que "los moscovitas, polacos, húngaros, alemanes, italianos, franceses y españoles no usan otra armonía de palabras", y añade a esta lista la de los "irlandeses, bretones, escoceses, daneses, sajones, ingleses", que la habrían incorporado algo más tarde.

La defensa de Daniel, en este punto, llega más lejos aún, y una buena parte de su Defensa de la rima está dedicada a reivindicar el notable valor de las aportaciones de aquellos a quienes Webbe, Ascham o Campion desprecian como bárbaros. Subraya Daniel la contribución de los godos, vándalos y lombardos en la elaboración de leyes y en la organización social, y destaca una serie de nombres que demuestran que el período medieval no es, en el ámbito de la cultura y el pensamiento, el yermo que los otros denuncian.

Con todo, la cultura clásica y el verso grecolatino son un punto de referencia constante en todo momento, tanto para los detractores como para los defensores de la rima. Puttenham expresa la idea, aceptada en general, de que la rima es un procedimiento que trata de compensar la pérdida de la cantidad: "puesto que, anhelando la fluidez del pie griego y latino, nosotros, en su lugar, creamos al final de nuestros versos un cierto sonido armonioso, que justo después concordamos con otro verso razonablemente distante en la caída final o cadencia, complaciéndose el oído al escuchar la armonía semejante repetida y sentir su regreso" (2004: 119-120). Varias décadas después lo vuelve a expresar Thomas Hobbes, que, al hablar del poema épico, señala que para sustituir los pies clásicos sirven los versos de diez sílabas -nuestros endecasílabos-, "que compensan el descuido de su cantidad con la diligencia de la rima" (1999: 610) -si bien advierte unas líneas más adelante que es una imprudencia dificultar en demasía el trabajo del poeta épico, y, recurriendo a la objeción clásica, subraya que "elegir una correspondencia de la rima innecesaria y difícil no es sino un juguete complicado" que obliga a veces al poeta "a decir aquello que nunca pensó" (1999: 611)-. 
La comparación con el verso clásico es ineludible, pero no siempre se acepta que el resultado del cambio tenga que ser necesariamente una pérdida. Pese al indiscutible prestigio que tiene la poesía grecolatina en la época renacentista, los valedores de la rima no se conforman con defender que es un procedimiento formal tan digno como el del modelo clásico, sino que, en algunos aspectos, y aduciendo distintas razones, llegan incluso a afirmar su superioridad. También en este punto sobresale Daniel, arrastrado muchas veces a la polémica por las ideas de Campion, su adversario. Si en alguna ocasión sostiene que el verso rimado es capaz de conmover "con un éxito tan feliz como el griego o el latino", la mayor parte de las veces insiste en que la rima mejora cuanto podía ofrecer el verso clásico. Se refiere varias veces a los versos latinos como simples números o números desnudos, y expresa su convencimiento de que, una vez que el lector ha descubierto esa nueva posibilidad y se ha acostumbrado a la cadencia armónica que es la rima, "los números latinos, a pesar de su excelencia, no parecen suficientes para satisfacer el oído del mundo" (2004: 211). La idea de Daniel es que la rima sólo ha implicado una ganancia para el verso; no resta nada, sólo aporta. Y sostiene de manera explícita, por lo tanto, que la rima es "una excelencia añadida a este trabajo de medida, y una armonía de lejos más feliz que cualquier proporción que la Antigüedad pudiera alguna vez habernos enseñado" (2004: 210). A fin de cuentas, él opina que la estructura del verso clásico reposa tan sólo en los números desnudos, pero el verso inglés rimado, teniendo también número, posee además medida y armonía, lo que "añade más gracia y contiene más deleite".

Llegando a un extremo desacostumbrado incluso entre los partidarios de la rima, Daniel no parece aceptar sin discusión la bondad del verso clásico, sino que lo somete a un juicio bastante severo. De hecho, en otra ocasión llega a sostener que el éxito de los versos latinos no se debe a su forma, sino a la "obra digna de admiración" a la que sirven de vehículo, esto es, al contenido (2004: 212), y más adelante se queja del desorden sintáctico que, según él, aqueja al verso grecolatino, y de las irregularidades que se encubren bajo la excusa de la licentia poetica (2004: 215). 
Esta atrevida crítica está de acuerdo con el rechazo explícito que puede observarse por parte de Daniel hacia todo argumento de autoridad: "Opino que no deberíamos entregar cautivo nuestro consentimiento tan pronto a la autoridad de la Antigüedad, a menos que veamos una mayor razón; todos nuestros conocimientos no han de ser construidos con la escuadra de Grecia e Italia" (2004: 217). Ironiza, además, sobre el hecho de que la datación se convierta en un criterio determinante para evaluar las bondades de un fenómeno estético; cerca ya del final de su obra, afirma Daniel que cuando la posteridad examine lo más valioso de su época bien pudiera ser que lo encuentre bajo la forma de la rima, algo que los detractores son incapaces de reconocer porque "estas cosas deben tener la fecha de la Antigüedad, para hacerlas respetables y auténticas" (2004: 229). En su opinión, todo debe justificarse por sus propias cualidades, y, sobre todo, teniendo en cuenta que, como se ha dicho, y como recuerda una vez más, "cada lenguaje tiene su número apropiado o la medida ajustada al uso y al deleite", algo que, continúa, es preservado por la costumbre y a lo que ésta "otorga carta de ciudadanía y hace normal" (2004: 210).

En todo caso, más interesantes parecen las consideraciones, tanto a favor como en contra de la rima, que no se basan en argumentos historicistas ni en la comparación con la métrica grecolatina, sino en sus cualidades intrínsecas y en los efectos que tiene sobre la obra, la escritura y la recepción del texto. Al margen de algunas ideas ya comentadas, como la de que la rima favorece la conservación de los versos en la memoria o la de que posee una sonoridad armoniosa que deleita el oído, es posible encontrar argumentos muy variados y que en ocasiones atañen a aspectos esenciales de la teoría literaria.

Uno de los puntos conflictivos en la polémica sobre la rima es el de su mayor o menor dificultad. Daniel refleja la opinión mayoritaria en la época cuando afirma que aquello que exige un mayor esfuerzo tiene, por eso mismo, más valor, y considera que el uso de la rima, en este sentido, es forzosamente mejor que el prescindir de ella: "donde nosotros más invertimos, por esa causa adquirimos el mayor éxito: y siendo la rima mucho más laboriosa que las medidas relajadas (por mucho que se objete) 
debe necesariamente, unida al ingenio y a la industria, producir más grandes y más valiosos efectos en nuestra lengua" (2004: 216). Thomas Campion coincide en reconocer el valor estético de la dificultad, pero eso le sirve, por el contrario, para despreciar la rima; en el capítulo segundo de sus Observaciones, que se titula "Sobre lo inapropiado de la rima en poesía", se lamenta con amargura de que la facilidad de la rima "crea tantos poetas como moscas un caluroso verano" (2004: 282). Cabe pensar que, en este caso, la facilidad que denuncia Campion se deriva de la comparación con el verso clásico, es decir, no es tanto que la rima en sí sea fácil cuanto que el tipo de verso que la utiliza posee un grado inferior de complejidad al del modelo que Campion defiende. Esa menor dificultad iría acompañada, como él mismo dice, de una mayor popularidad, que iría en detrimento del nivel de la producción literaria.

En general, sin embargo, se suele admitir que la rima es un elemento que introduce un grado superior de dificultad en la creación poética. Esa impresión está en la raíz de algunas de las denuncias que ya se han comentado, como la de que impide al poeta decir lo que en un principio se proponía o, por el contrario, le obliga a escribir aquello que no quería, desviándole en cualquiera de los casos de su primera intención. El buen poeta será el que se muestra capaz de vencer esas dificultades y satisfacer las exigencias de la rima mediante su dominio del idioma y de la técnica de la versificación, sin que ello le desvíe de su propósito. George Puttenham, después de su exposición sobre la distancia de las rimas en el esquema de las estrofas, propone un ejercicio mediante el que podemos examinar la valía del poeta, su dominio del léxico, su ingenio y la bondad de su memoria; el ejercicio consiste en imponerle un número de versos (pueden ser, además, de medida desigual, que también habría que especificar), unir con líneas curvas aquellos que deben rimar entre sí, y por último proponerle un primer verso -"no importa que tenga o no un sentido completo", subraya reconociendo de manera implícita que el verso es una unidad rítmica, no semántica-; "si comprobáis que el creador respeta las medidas y la rima tal como se le ha señalado, y más allá construye una canción comprensible y enlazada al primer 
verso de forma razonable, entonces podéis decir que es dueño de su oficio" (2004: 130).

Daniel, no obstante, sumando con ello un nuevo argumento a favor de la rima, le da un giro a la objeción de la dificultad y sostiene que la consonancia - no importa que implique una tarea más laboriosa- resulta ser más bien un valioso auxiliar para el poeta. Toma como ejemplo el soneto para afirmar que la rima no supone un obstáculo para sus evidentes logros, sino lo contrario, puesto que es capaz de producir "un concepto más allá de lo esperado". La idea implícita en éste y en otros razonamientos semejantes es la de que, por causa de las analogías sonoras y la indudable exigencia que impone la consonancia, el creador se ve conducido por ésta hasta ideas que de otra manera no habría alcanzado, que habrían quedado al margen de su imaginación. Lo que para otros autores es una limitación, para Daniel es una ventaja, tal como puede verse en la siguiente afirmación (2004: 215-6):

"Con seguridad, en un espíritu eminente al que la naturaleza ha formado para ese menester, la rima no es impedimento para su facultad de concebir, sino que más bien le da alas para remontar y le lleva, no fuera de su camino, sino, como si estuviera más allá de su poder, a un vuelo de largo más feliz".

Se trata de uno de los muchos argumentos que es dado encontrar en defensa de la idea de que, pese a las apariencias, y como ilustra la parábola kantiana de la paloma que afianza sus alas en la resistencia del aire, las dificultades formales que el escritor acepta o se impone tienen a menudo la facultad de actuar como un estímulo de su creatividad.

Tanto Campion como Daniel expresan sus opiniones al respecto empleando, pese a que son radicalmente opuestas, un mismo motivo: la esclavitud. Campion escribe, en un poema corto que aduce como ejemplo de su propuesta de versificación: "Poore English Poesie as the slaue to rime" (1815: 170). Y Daniel, por el contrario, le responde: "De manera que si nuestros esfuerzos han producido la manumisión de nuestra esclavitud, y vamos libremente, a pesar de esos lazos, ya no somos esclavos 
de la rima, sino que la convertimos en un excelente instrumento que nos sirve" (2004: 216), afirmación ésta que invierte los términos y que anticipa la célebre frase que Boileau incluirá bastantes décadas más tarde en el "Canto I" de su Arte poética: "La rime est une esclave et ne doit qu'obéir" (1873: 144).

En este sentido, el misterioso E.K. que firma el mencionado prólogo de The Shepheardes Calender se burla de los efectos de la rima sobre el proceso de la creación poética, que por su causa se convertiría en algo irracional y arbitrario; la rima, según él, despoja de su sentido común al poeta, que se comportaría "como la misma Pitia, cuando le sobrevenía el trance" (SPENSER, 1890: 40). Al igual que en otras críticas antes analizadas que oponían la rima a la razón, E.K. considera que los trabajos y las exigencias de la rima, que por todo ello no debería considerarse un recurso productivo, provocan que el poeta olvide su concepto anterior.

De vuelta a las Observaciones sobre el Arte de la Poesía Inglesa de Campion, pueden hallarse otros ataques contra la rima que son algo más imprecisos, o que se producen de pasada, sin que vayan acompañados de razones que los apoyen. Ya desde la dedicatoria a Lord Buckhurst, el autor exhibe su desprecio por la rima, a la que acusa de vulgar y unarteficiall -término éste que habría que interpretar como "falto de artificio" en el sentido de "contrario al arte", no en el de "natural"-, y añade que la "costumbre de rimar ha disuadido a muchos ingenios excelentes del ejercicio de la poesía inglesa" (1815: 161).

Más tarde, ya en el cuerpo de la obra, afirma Campion, por ejemplo, que los poemas basados en números -los que usan el modelo clásico, métrico-, son los más agradables, pese a que "algunos oídos acostumbrados por completo a la gruesa rima pueden tal vez objetar contra los finales de estos números"; insiste, sin embargo, en que cualquier hombre juicioso que los examine descubrirá que se cierran a la perfección, y "que la ayuda de la rima no sólo sería superflua en ellos, sino también absurda" (2004: 287). Daniel responde a lo primero, en tono jocoso, que no ve la ventaja, pues si los ignorantes siguen la propuesta de Campion producirán números magros en lugar de rimas gruesas (2004: 228). En cuanto a lo segundo, unas páginas antes, Daniel 
considera, al contrario que Campion, que la rima tiene un papel importante como elemento que marca dónde termina el verso.

Daniel hace una reflexión general sobre la idea de que los límites son convenientes e incluso necesarios para la percepción de la armonía. Es un pensamiento que aparece diseminado por su ensayo de manera casi recurrente. Lejos todavía de reconocer el papel que la pausa final desempeña en la estructura del poema, y como era dado esperar, entiende que la mejor forma de señalar el final del verso, y en consecuencia reconocer su armonía y disfrutarla, es mediante la rima: “¿no es mas placentero para la naturaleza -que desea una certeza y no armoniza con aquello que es infinito- tener estas cadencias, antes que desconocer dónde terminar, o cuán lejos proseguir?" (2004: 216). La rima, pues, serviría de ayuda no sólo al poeta cuando crea, sino también al lector cuando lleva a cabo la lectura del verso.

La polémica sobre la rima no sólo se centra en sus efectos y características y en la conveniencia de su uso, sino que se extiende a los orígenes del término y a la medida en que éste es o no apropiado. Es lugar común en la mayor parte de estos estudios la revisión de la etimología. Los detractores de la rima tienden incluso a expresar su desprecio hacia la rima señalando lo erróneo del término. Es lo que hace Campion, que ya desde el principio de su obra se refiere a "esa clase de poesía vulgar y fácil que de forma abusiva llamamos rima" (2004: 282), término, sigue diciendo, que derivaría de rithmus, algo que, como explica Gavin Alexander en las notas, le resultaría inaceptable por cuanto denotaría un determinado patrón rítmico que no debería aplicarse al verso moderno. Ya con anterioridad, George Puttenham, que no puede ser considerado un detractor de la rima, había afirmado igualmente que "usamos la palabra rima de manera abusiva", y explica que el término originario en griego era rhythmos -equivalente, dice, a numerosity-, "una palabra tomada en préstamo de los griegos por los latinos y los franceses", de quienes, a su vez, la tomaron más tarde los anglosajones (2004: 120).

También se libra la disputa de una manera soterrada mediante el uso de otros términos relativos a la rima, que llegan a convertirse en una especie de arma arrojadiza. Hay una palabra en concreto, rimer, que los enemigos de la rima convierten en un 
insulto, en tanto que sus defensores tratan de utilizarla despojándola de las connotaciones despectivas que, en general, tiene -al igual que sucede en el español actual, donde la única acepción recogida por la Academia es la de "que se distingue en sus composiciones poéticas más por la rima que por otras cualidades"-. Ya se ha visto con anterioridad cómo Webbe o Spenser hablaban de los rústicos y andrajosos rimadores, y también Campion usa la palabra con evidente desprecio. Es significativo el hecho de que Puttenham, que no está en contra de la rima, suele usar el término, a veces en oposición a maker, cuando censura una práctica determinada o se refiere a ciertas características negativas del poeta; utiliza la palabra cuando alude a quienes traicionan la correcta escritura de la palabra con motivo de la rima, cuando critica la vulgaridad de Skelton -rimador jocoso-, o para hablar de poetas comunes que se dedican a escribir poemas insustanciales.

Daniel, sin embargo, cuando emplea dicho término lo hace en un claro tono reivindicativo y orgulloso. Muy al principio de su Defensa, declara que la polémica sobre la versificación es un asunto que concierne "a todo rimador de esta isla universal, como a mí mismo" (2004: 209), afirmación en la que se identifica -si no se incluye en él de manera clara y explícita- con el colectivo de los rimadores. Pero más claro aún es el valor encomiástico de la palabra cuando, unas páginas después, al elogiar a los intelectuales más destacados del pasado, destaca entre todos ellos a Tomás Moro: "un gran motivo de orgullo para esta tierra y un rimador" (2004: 219). No es casual que elija precisamente esa palabra, que en este contexto sirve para subrayar los méritos de Moro y, al mismo tiempo, se beneficia del prestigio que tiene aquél a quien se aplica.

Cerca ya del final de su obra, en medio de una exhortación en favor del uso de la rima, Daniel prefiere emplear una perífrasis y, en lugar de rhymer, utiliza writer in rhyme. Se trata de un párrafo que, en definitiva, resume fielmente el ánimo de su escrito; se observa en él un tono belicoso -contra Campion- y reivindicativo - de la rima-, así como un sentido solidario que le une a los otros poetas que usan la rima, a los que se dirige en los siguientes términos (2004: 229): 
"Y que ningún escritor en rima se vea de ninguna manera desanimado en su esfuerzo por esta jactanciosa voz de alarma, sino más bien animado para reunir lo mejor de sus facultades, y acometer con toda la fuerza de la naturaleza y la industria contra el desprecio, de modo que la exhibición de sus fuerzas reales pueda devolver la insolencia a su propia guarida".

En definitiva, son dos visiones completamente opuestas las que contienden en este asunto, en el que, como se ha podido comprobar a lo largo de estas páginas, entran en juego aspectos de órdenes muy diversos, desde lo gramatical a lo pragmático, de lo fónico a lo estructural, y casi siempre teniendo en cuenta la dificultad añadida y el riesgo de desequilibrio entre la forma y la idea que la rima introduce y supone. En todo caso, como también se ha visto, muchos de los argumentos que se esgrimen en esta polémica no son sino la munición que cada contendiente tiene a su alcance y que emplea dentro del contexto más amplio de un enfrentamiento entre la reivindicación de los modelos clásicos y la de un verso sin raíces nobles pero más adecuado a la prosodia y la sensibilidad del momento. Sin embargo, la polémica es más compleja y también excede ese debate. Por una parte, la rima no sólo se enfrenta al pasado clásico, sino también a la renovación que constituye el verso blanco. Además, se ha podido ver que hay una clara voluntad de comparación -en general orgullosacon lo que se hace en las naciones vecinas de la Europa continental. No se debe olvidar que, en este tiempo, Inglaterra está construyendo y defendiendo una nueva identidad política y religiosa, lo que explica que las polémicas se multipliquen en todos los ámbitos, llegando a afectar, y con no poca pasión, a éste de la versificación y, más concretamente, a un asunto tan importante dentro de ella y tan rico en implicaciones como es la rima. 


\section{Bibliografía citada}

ASCHAM, Roger: (1898) The Scholemaster, Heath \& co., Boston.

ALEXANDER, Gavin (ed.): (2004) Sidney's The Defense of Poesy and Selected Renaissance Literary Criticism, Penguin, Londres.

BAEHR, Rudolf: (1989) Manual de versificación española, Gredos, Madrid.

BELTRAMI, Pietro: (1994) La metrica italiana, Il Mulino, Bolonia.

BOILEAU, Nicolas: (1873) L'Art poétique, en Oeuvres Complètes, Fournier, Paris.

CAMPION, Thomas: (1925) Observations in the Art of English Poesie, Dutton, New York.

CHAPMAN, George: (1888) "To the reader", en The Iliads of Homer done according to the Greek, Vol. I, John Russell Smith, Londres.

DANIEL, Samuel: (2004) A Defence of Rhyme, en Sidney's The Defense of Poesy and Selected Renaissance Literary Criticism, Penguin, Londres.

DEVOTO, Daniel: (1995) Para un vocabulario de la rima española, Annexes des cahiers de linguistique hispanique médiévale, vol. 10, París.

DOMÍNGUEZ CAPARRÓS, José: (1999) Diccionario de métrica española, Alianza, Madrid.

FRAU, Juan: (2003) "Sobre la Comparación Métrica en la Poética Clasicista", en Exemplaria: Revista de Literatura Comparada. Núm. 7, pags. 261-272.

HARINGTON, John: (1815) An Apologie of Poetrie, en Ancient Critical Essays upon English Poets and Poesy, vol. II, Haslewood, Londres.

HARVEY, Gabriel y SPENSER, Edmund: (1815) Two other commendable letters, en Ancient Critical Essays upon English Poets and Poesy, vol. II, Haslewood, Londres.

HOBBES, Thomas: (1999) "On epic poetry", en Vickers, Brian (ed.): English renaissance literary criticism, Oxford University Press.

JAKOBSON, Roman: (1974) "La lingüística y la poética", en SEBEOK, T. A. (ed.): Estilo del lenguaje, Cátedra, Madrid, págs. 123-173.

MERES, Francis: (1815) Palladis Tamia. A comparatiue discourse of our English Poets, with the Greeke, Latine, and Italian Poets, en Ancient Critical Essays upon English Poets and Poesy, vol. II, Haslewood, Londres. 
NEBRIJA, Antonio de: (1989) Gramática de la lengua castellana, Centro de Estudios Ramón Areces, Madrid.

PUTTENHAM, George: (2004) The Art of English Poesy, en Sidney's The Defense of Poesy and Selected Renaissance Literary Criticism, Penguin, Londres.

(1811) The Arte of English Poesie, en Ancient Critical Essays upon English Poets and Poesy, vol. I, Haslewood, Londres.

SHAKESPEARE, William: (1967) Los dos hidalgos de Verona, Aguilar, Madrid.

- (1986) The complete Works, Clarendon Press, Oxford.

SIDNEY, Philip: (2004) Sidney's The Defense of Poesy and Selected Renaissance Literary Criticism, Penguin, Londres. (2003) Defensa de la poesía, Cátedra, Madrid.

SPENSER, Edmund: (1890) The Shepheardes Calender, J. C. Nimmo, Londres.

SPENSER, Edmund y HARVEY, Gabriel: (1815) Three proper and wittie, familiar letters, en Ancient Critical Essays upon English Poets and Poesy, Haslewood, Londres.

SYMONDS, John A.: (1895) Blank verse, J. C. Nimmo, Londres.

TORRE, Esteban: (2000) Métrica española comparada, Universidad de Sevilla, Sevilla.

WEBBE, William: (1870) A Discourse of English Poetrie, Arber, Londres.

WEINBERG, Bernard: (2003) Estudios de poética clasicista, Arco/ Libros, Madrid.

WESLING, Donald: (1980) The Chances of Rhyme. Device and Modernity, University of California Press, Berkeley.

WILSON, Thomas: (1909) Arte of Rethorique, Clarendon Press, Oxford. 